\title{
Państwo wspierające a rozwój gospodarczy: rola państwa w Nowej Ekonomii Strukturalnej ${ }^{1}$
}

\begin{abstract}
Artykuł analizuje koncepcje rozwoju i roli państwa w rozwoju gospodarczym oraz ich wpływ na przemiany instytucjonalne z punktu widzenia Nowej Ekonomii Strukturalnej. Wysunięto tezę, że struktury ekonomiczne - włącznie ze strukturą techniki i przemysłu oraz infrastruktury twardej i miękkiej - mają charakter endogeniczny względem struktury uposażenia, która jest dana w każdej konkretnej chwili i zmienna w czasie. Opowiedziano się za rolą państwa w zakresie ułatwiania przemian strukturalnych poprzez wykorzystanie polityki przemysłowej do naprawiania niedomagań rynku. Działania takie winny wspomagać branże przemysłu cechujące się ukrytymi przewagami komparatywnymi i ułatwiać im zyskanie konkurencyjności na rynku. Państwo winno wykorzystywać swoje ograniczone zasoby i zdolności wdrożeniowe w sposób pragmatyczny, przyznając priorytet tworzeniu enklaw o korzystnej infrastrukturze i rozwijaniu instytucji, aby pobudzać dynamiczny wzrost w krajach o zasadniczo ubogiej zastanej infrastrukturze i sieci instytucjonalnej.
\end{abstract}

Słowa kluczowe: rola państwa, rozwój gospodarczy, Nowa Ekonomia Strukturalna.

\section{Wprowadzenie}

Po drugiej wojnie światowej wiele krajów uzyskało polityczną niezależność i weszło na ścieżkę modernizacji. W odpowiedzi na potrzebę budowania państwa w krajach rozwijających się wyłoniła się nowa poddyscyplina współczesnej ekonomii: ekonomia rozwoju. Spodziewano się, że będzie ona przeprowadzać te kraje przez proces industrializacji i pomoże im w osiągnięciu dobrobytu.

Wyniki jednak rozczarowują, ponieważ wśród prawie 200 rozwijających się gospodarek jedynie Korea Południowa i Tajwan (Republika Chińska) zdołały podnieść swój status do państwa o wysokim dochodzie (Lin i Rosenblatt, 2014)2, a wśród 110 gospodarek o średnich dochodach w latach 60. XX wieku tylko

1 Opublikowano w: Man and the Economy, 4(2), grudzień, 2017, s. 1-19.

2 Chiny kontynentalne mogą stać się trzecią gospodarką, która zmieni status z państwa o niskich na państwo o wysokich dochodach około roku 2025. 
trzynaście zmieniło status na gospodarki o wysokim dochodzie (Agenor i in., 2012). Z tych trzynastu gospodarek osiem było zaś albo krajami ościennymi Europy Zachodniej, w których dystans do krajów rozwiniętych był niewielki już na starcie, albo krajami produkującymi ropę. Pozostałe pięć to Japonia, Korea, Tajwan, Hongkong i Singapur.

Nowatorski model wzrostu Solowa prognozuje konwergencję dochodów, zgodnie z którą kraje ubogie powinny rozwijać się szybciej niż bogate z powodu zjawiska malejących przychodów z kapitału (Solow, 1956). Niemniej, pomimo wysiłków podejmowanych przez kraje rozwijające się oraz wielostronnej pomocy wielu agencji rozwoju, większość z tych gospodarek nie dogoniła gospodarek o wysokich dochodach, co warto przeanalizować.

Mankiw i in. (1992) argumentują, że rozszerzony model Solowa, obejmujący gromadzenie kapitału ludzkiego i fizycznego, stanowi doskonały opis danych występujący między krajami. Zgodnie z zasadą, podobną jak w wypadku kapitału fizycznego, niższy poziom kapitału ludzkiego powinien oznaczać wyższą stopę zwrotu. Jednakże biedne kraje nie są w stanie zgromadzić wystarczającej ilości kapitału ludzkiego z powodu deficytu inwestycji w wysokiej jakości edukację, a także znacznych problemów z „drenażem umysłów”. Problem ten porównywany jest do zjawiska ucieczki kapitału z krajów ubogich do zamożnych (Lucas, 1990). Zatem mniejsze kapitały fizyczny i ludzki muszą wynikać $\mathrm{z}$ bardziej fundamentalnego zjawiska, które leży u podstaw niepowodzenia rozwojowego.

Jak twierdzi Kuznets (1966), obecnie wzrost dochodów ma charakter procesu nieprzerwanych transformacji strukturalnych z ciagłymi innowacjami technologicznymi $\mathrm{w}$ istniejących branżach oraz $\mathrm{z}$ pojawianiem się nowych branż o wyższej wartości dodanej, które podnoszą produktywność pracy i ulepszeń infrastruktury - zarówno ciężkiej, czyli materialnej, jak i miękkiej, czyli niematerialnej, w tym instytucjonalnej. Wszystkie te innowacje i ulepszenia obniżają koszty transakcyjne gospodarki. Ponieważ kraje rozwijające się są stosunkowo zacofane pod względem technologii i przemysłu, powinny mieć większy potencjał wzrostu niż kraje rozwinięte i osiągać konwergencję z uwagi na łatwość podnoszenia poziomu swoich technologii i przemysłu (Gerschenkron, 1962). Jednakże od czasu drugiej wojny światowej większość krajów rozwijających się nie wykorzystała tych możliwości i utknęła w segmencie państw o dochodach niskich lub średnich.

Argumentuje się, że skuteczne i sprawne instytucje są kluczem do wzrostu gospodarczego i że to właśnie rozwój tych instytucji w Europie Zachodniej przyczynił się do ukształtowania nowoczesnego Zachodu (zob. North i Thomas, 
1976; North, 1990; Acemoglu i Robinson, 2012). Powszechnie przyjmuje się także, że instytucje są oporne na zmiany i jest mało prawdopodobne, aby źle funkcjonujące instytucje w danym kraju uległy samoczynnej naprawie (North, 1990; Acemoglu i in., 2001). Kraje, które posiadają sprawniejsze instytucje, bezpieczniejsze prawo własności i mniej wypaczoną politykę będą również więcej inwestowały w kapitał fizyczny i ludzki. Będą wykorzystywały te czynniki efektywniej dla osiągnięcia wyższego poziomu dochodów (Acemoglu i in., 2001). Jednak czy w krajach, w których niewydolne instytucje hamują wzrost gospodarczy istnieje sposób, aby je zreformować i rozwinąć gospodarkę - zmienić bieg historii zamiast cofać się w czasie?

Jak powiedział Keynes (1935, s. 384), „to idee, a nie konkretne interesy stanowią groźną broń w służbie dobra lub zła”. W artykule tym postawiono tezę, że słabe postępy w rozwoju większości krajów rozwijających się wynikają z niewłaściwych pomysłów na ścieżkę rozwoju i rolę państwa. Niniejszy artykuł omawia koncepcje rozwoju i rolę państwa w rozwoju gospodarczym i zmianach instytucjonalnych z perspektywy Nowej Ekonomii Strukturalnej (Lin, 2011; 2012).

Zdaniem autorów niniejszego artykułu, państwo wspiera rozwój gospodarczy poprzez przezwyciężanie nieodłącznych nieprawidłowości w funkcjonowaniu rynku, związanych z przemianami technologicznymi, modernizacją przemysłu i ulepszeniami infrastruktury twardej i miękkiej. Nieprawidłowości takie wynikają z różnych efektów zewnętrznych, z roli pierwszych graczy oraz z problemów $\mathrm{z}$ koordynacją, jakie pojawiają się w procesie poprawy twardej infrastruktury i instytucji w ramach transformacji strukturalnej.

Dynamiczny rozwój gospodarki wymaga organicznego związku między rynkiem a państwem, który polega na tym, że rynek jest wydajny tylko wtedy, gdy państwo ułatwia przezwyciężanie nieprawidłowości w działaniu rynku, a czyni to w celu zapewnienia wydajności rynku. Stwierdzono również, że jeżeli zasadnicze koncepcje są prawidłowe, to państwo rozwijające się - bez względu na to czy jest silne, czy słabe - może w sposób pragmatyczny podejmować i realizować politykę pobudzającą dynamiczny wzrost, pomimo istniejących niedomagań w postaci słabo rozwiniętej infrastruktury i instytucji. Nie wysunięto postulatu zwiększenia zakresu kontroli państwa nad rynkiem ani pogłębiania interwencjonizmu. Stwierdzono jedynie, że ułatwiająca rola państwa jest koniecznym warunkiem rozwoju i jedynie posiadanie i realizacja właściwych pomysłów pozwalają krajom rozwijającym się na pobudzenie i utrzymanie dynamicznego wzrostu gospodarczego.

Artykuł ma na celu zaprezentowanie nowej teorii państw ułatwiających rozwój gospodarczy. W pierwszej kolejności omówiono wcześniejsze koncepcje ekonomii rozwoju z naciskiem na ich poglądy na temat roli państwa. Następnie 
przedstawiono główne idee Nowej Ekonomii Strukturalnej i z jej perspektywy przedstawiono rolę państwa.

\section{Poprzednie generacje ekonomii rozwoju ${ }^{3}$}

\subsection{Ekonomia rozwoju 1.0: strukturalizm}

Pierwszą generacją ekonomii rozwoju był strukturalizm. Po drugiej wojnie światowej wiele krajów rozwijających się dążyło do zapewnienia swoim obywatelom takiego standardu życia, jaki zdobyły społeczeństwa świata rozwiniętego. Warunkiem realizacji tego celu było osiągnięcie w kraju rozwijającym się takiego samego dochodu i wydajności pracy, jak w krajach rozwiniętych. To z kolei wymagało posiadania równie zaawansowanego przemysłu, tymczasem rzeczywistość krajów rozwijających się była inna - dominowały w nich tradycyjne rolnictwo i eksploatacja zasobów naturalnych.

$\mathrm{Na}$ ambicję stworzenia zaawansowanego przemysłu w krajach rozwijających się równie silnie wpływało pogorszenie warunków wymiany handlowej między eksporterami surowców a importerami produktów przemysłowych w latach 30 . i 40. XX wieku od czasu Wielkiego Kryzysu. Przywódcy polityczni i elity społeczne w wielu krajach Ameryki Łacińskiej dostrzegały nieustanny spadek cen dóbr eksportowanych (produktów podstawowych, surowców) i trwałe pogarszanie się ich stosunku do cen dóbr importowanych. Zjawisko to powodowało przepływ dochodów z bogatych w zasoby krajów rozwijających się do bogatych w kapitał krajów rozwiniętych. W tej sytuacji uznano, że pomysłem na uniknięcie takiego wykorzystywania krajów rozwijających się przez kraje rozwinięte będzie zapewnienie warunków do krajowej produkcji przemysłowej poprzez stopniową substytucję importu. Jednocześnie, przemianie byłych kolonii lub półkolonii w nowe niepodległe państwa w Azji i na Bliskim Wschodzie, a później także w Afryce, towarzyszyły silne nastroje nacjonalistyczne.

Z punktu widzenia strukturalizmu kraje rozwijające się nie mogły zbudować nowoczesnego przemysłu, ponieważ na przeszkodzie stały istniejące sztywne struktury państwowe, które osłabiały działanie rynku i uniemożliwiały samoczynny rozwój przemysłowy. Strukturalizm opowiada się za państwem rozwojowym i zaleca rządom krajów rozwijających się przyjęcie strategii substytucji importu wraz z odpowiednią polityką cenową i mobilizacją na rzecz rozwijania zaawansowanego, nowoczesnego przemysłu. Podejście takie było również

3 Ta część nawiązuje do: Lin, 2011; Lin i Rosenblatt, 2012. 
zgodne z dominującą w tym okresie doktryną interwencjonizmu państwowego Keynesa. Realizując strategię substytucji importu, wiele krajów rozwijających się przeżywało okres inwestycyjnego wzrostu, choć przerywanego okresami zastoju i częstych kryzysów. Zjawiska te dodatkowo zwiększyły różnicę w dochodach krajów rozwiniętych i rozwijających się.

\subsection{Ekonomia rozwoju 2.0: neoliberalizm}

O ile realizowane przez rządy strategie rozwoju gospodarczego oparte na strukturalizmie poniosły porażkę $w$ wielu krajach, o tyle doktryna wolnego rynku zdawała się triumfować i wpływać na myślenie o rozwoju. Dominująca keynesowska makroekonomia została zakwestionowana w okresie stagflacji lat 70., kryzysu zadłużeniowego Ameryki Łacińskiej oraz upadku socjalistycznego systemu planowania w latach 80 . Pojawiła się wówczas tzw. rewolucja racjonalnych oczekiwań, która obaliła podstawy teoretyczne strukturalizmu dotyczące roli państwa i jego polityki fiskalnej oraz pieniężnej w rozwoju gospodarczym.

W latach 80. pojawił się natomiast neoliberalizm. Trend ten interwencje rządu uznawał za główną przyczynę niepowodzenia krajów rozwijających się w doganianiu krajów rozwiniętych, a w ich miejsce zalecał zestaw wytycznych polityki neoliberalnej wspierany konsensusem waszyngtońskim. Miało to eliminować interwencję rządu w procesy gospodarcze i zapobiegać jego nietrafnym decyzjom (Williamson, 1990). Neoliberalizm promuje zatem liberalizację gospodarki, prywatyzację i opowiada się za minimum państwa, doradzając krajom rozwijającym się ukształtowanie dobrze funkcjonujących instytucji rynkowych na wzór krajów rozwiniętych. Wyznawcy tej koncepcji wierzyli, że gdy rynek zacznie dobrze funkcjonować, dynamiczny rozwój i transformacja strukturalna nastąpią samoczynnie.

Zgodnie z wytycznymi konsensusu waszyngtońskiego wiele z krajów rozwijających się zastosowało w latach 80. i 90. „terapię szokową” w celu wdrożenia programów dostosowań strukturalnych. Interwencje rządu zastąpiła polityka doradztwa i wsparcia finansowego ze strony takich międzynarodowych instytucji, jak Bank Światowy czy Międzynarodowy Fundusz Walutowy. Zamysł dostosowania strukturalnego był słuszny, a analiza ekonomiczna tych programów wyglądała wiarygodnie i przekonująco, jednak wynik nie okazał się satysfakcjonujący. Tempo wzrostu w dwóch ostatnich dekadach XX wieku w wielu krajach rozwijających się było jeszcze niższe niż w latach 60 . i 70., a kryzysy jeszcze częstsze. W niejednym spośród nich mówiło się o straconych dekadach i nic dziwnego, skoro różnice dochodowe pomiędzy krajami rozwiniętymi i rozwijającymi się rosły coraz bardziej (Easterly, 2001). 


\section{Nowa generacja ekonomii rozwoju}

\subsection{Nowa Ekonomia Strukturalna}

Według raportu Banku Światowego z 2008 roku (Commission on Growth and Development, 2008) na temat wzrostu gospodarczego, po drugiej wojnie światowej trzynaście gospodarek osiągnęło wyjątkowy wynik, rosnąc średnio o co najmniej 7\% nieprzerwanie przez ok. 25 lat. Ta wygrana trzynastka posiadała pięć następujących cech wspólnych: 1) były to gospodarki otwarte; 2) utrzymywały stabilność makroekonomiczną; 3) miały wysokie oszczędności i wysokie stopy inwestycji; 4) utrzymywały dobrze funkcjonujący mechanizm rynkowy lub przynajmniej zmierzały w kierunku gospodarki rynkowej; 5) działały w nich wiarygodne, zaangażowane i proaktywne rządy.

Michael Spence, przewodniczący Komisji ds. Wzrostu Gospodarczego i Rozwoju (Commission on Growth and Development), podkreśla, że te pięć cech to wprawdzie składniki sukcesu, ale jeszcze nie przepis na sukces. Zdaniem autorów niniejszego artykułu, potrzebna jest nowa ekonomia rozwoju, która jest w stanie zapewnić spójną strategię obejmującą tych pięć cech skutecznie rozwijających się gospodarek. Ponadto, musimy zapewnić praktyczne wytyczne, którymi rządy krajów rozwijających mogłyby się kierować.

Trzecia generacja rozwoju, zaproponowana przez Lina (2011; 2012), określana mianem Nowej Ekonomii Strukturalnej, jest zastosowaniem podejścia neoklasycznego do badania czynników wpływających na strukturę gospodarczą, zmiany strukturalne i ich wpływu na ewolucję rozwoju. Jak wyjaśnia Rodrik (2011), „kraje rozwijające się różnią się jakościowo od krajów rozwiniętych - nie są one jedynie promieniowo pomniejszonymi wersjami krajów bogatych. Aby zrozumieć wyzwania związane z opóźnieniami w rozwoju, trzeba zrozumieć, w jaki sposób ustalane są struktury zatrudnienia i produkcji, a zwłaszcza duże rozbieżności pomiędzy społecznym marginalnym produktem pracy w działaniach tradycyjnych w stosunku do działań nowoczesnych - i jak można pokonać przeszkody, które blokują przemiany strukturalne".

Głównym argumentem Nowej Ekonomii Strukturalnej jest, że struktury gospodarcze, w tym struktura technologii i przemysłu określająca wydajność pracy oraz twarda i miękka infrastruktura, która określa koszty transakcyjne są endogenne dla wyposażenia kapitałowego podanego w dowolnie określonym okresie i zmiennego w czasie.

Wyposażenie kapitałowe i struktura wyposażenia kapitałowego decydują o całkowitym budżecie gospodarki i względnych cenach czynników w dowolnie określonym czasie. Te z kolei określają przewagę konkurencyjną i optymalną 
strukturę przemysłową. Oznacza to, że gdy struktura przemysłowa jest zgodna z przewagą komparatywną określaną przez strukturę wyposażenia kapitałowego, będzie miała najniższy współczynnik kosztów produkcji na rynkach krajowych i międzynarodowych. W związku z tym, kiedy struktura gospodarki w zakresie stanu zasobów awansuje z jednego poziomu rozwoju na inny, odpowiednio rozwijać się będzie optymalna struktura przemysłowa danej gospodarki.

Wzrost dochodów zależy od modernizacji struktury przemysłowej, której celem jest zwiększenie wydajności pracy. Ta z kolei zależy od modernizacji struktury wyposażenia przechodzącego od branż pracochłonnych do kapitałochłonnych. Wraz z modernizacją struktury przemysłowej wymagane są ulepszenia twardej i miękkiej infrastruktury w celu obniżenia kosztów i ryzyka transakcji.

Drugim najlepszym sposobem osiągnięcia dynamicznego wzrostu i konwergencji - zaraz po przewadze komparatywnej (określonej przez strukturę zasobów) - jest rozwój różnych branż przemysłu. Gospodarka posiadająca rozwinięty przemysł i odpowiednią twardą i miękką infrastrukturę będzie najbardziej konkurencyjna, będzie też produkować największą nadwyżkę, generować największe możliwe zyski z kapitału, a tym samym oszczędności, jak również gwarantować najszybsze ulepszenie struktury wyposażenia kapitałowego i osiągnięcie najszybszej modernizacji przemysłu i wzrostu dochodów (Ju, Lin i Wang, 2015). W tym procesie kraj rozwijający się może czerpać korzyści ze swojego późnego startu i dzięki temu realizować innowacje technologiczne i przemysłowe szybciej niż kraje o wysokim dochodzie, co z kolei prowadzi do szybszego wzrostu i konwergencji z krajami o wysokim dochodzie.

Przedsiębiorców z kolei interesuje rentowność. Jak przełożyć ideę podążania za przewagą komparatywną kraju na wpływ na spontaniczne decyzje przedsiębiorców? Wymaga to dobrze funkcjonującego rynku - tak, aby względne ceny czynników odzwierciedlały ich względną podaż w wyposażeniu kapitałowym. Przy takich względnych cenach czynników przedsiębiorcy będą w interesie własnej rentowności i konkurencyjności na rynku angażować się w przemysł i stosować technologie zgodne z przewagą komparatywną określoną przez wspó1czynnik zasobów.

Rozwój gospodarczy jest jednak procesem dynamicznym. Jest to proces ciągłych innowacji technologicznych i modernizacji przemysłu. Takie modernizacje i ulepszenia wymagają kogoś, kto wykona pierwszy ruch. W trakcie tego procesu pojawiają się dwa problemy związane z niedoskonałością rynku. Pierwszym z nich jest czynnik zewnętrzny, tzn. rząd musi stworzyć zachętę dla pierwszego gracza. Drugim jest koordynacja w celu poprawy instytucji i infrastruktury, które mają wpływ na koszty transakcji i na prawdopodobieństwo sukcesu pierwszych 
graczy. Tak więc, oprócz skutecznego mechanizmu rynkowego potrzebny jest rząd odgrywający aktywną rolę w ułatwianiu zmian strukturalnych.

Te dwa warunki, skuteczny rynek i państwo ułatwiające, to właśnie stylizowane fakty 4 i 5 z raportu na temat wzrostu gospodarczego. Jeśli kraj podąża za swoją przewagą komparatywną w rozwoju, otworzy swoją gospodarkę na rynek światowy (fakt 1) i osiągnie stabilność makroekonomiczną ze względu na swoją konkurencyjność (fakt 2). Podążanie za przewagą komparatywną wygeneruje największe nadwyżki i najlepsze zachęty do oszczędności i inwestycji (fakt 3). Zatem podążanie za przewagą komparatywną jest receptą na sukces w zakresie rozwoju gospodarczego (Lin, 2012, rozdz. 2).

Z perspektywy Nowej Ekonomii Strukturalnej strukturalizm zawiódł, ponieważ zignorowano endogeniczność struktury ekonomicznej kraju i zalecono promocję niektórych gałęzi przemysłu - zbyt zaawansowanych względem poziomu rozwoju kraju i przeciwstawiających się przewadze komparatywnej tego kraju. Przedsiębiorstwa takie były nierentowne na otwartych rynkach konkurencyjnych i wymagały subwencji rządowych oraz ochrony inwestycji początkowych, a także ciągłości działalności. Doprowadziło to do niewłaściwej alokacji zasobów, pogoni za rentą korupcji i zawłaszczania politycznego. Odnoszące sukcesy gospodarki Azji Wschodniej postąpiły inaczej: przyjęły strategie zorientowane na eksport w celu rozwinięcia pracochłonnej produkcji i wykorzystały przewagę komparatywną, jaką stanowily ich bogate zasoby siły roboczej w latach 50. i 60 . Strategia ta nie zaliczała się do tych, które zalecał strukturalizm.

Z kolei konsensus waszyngtoński oparty na neoliberalizmie również zawiódt, ponieważ zignorowano fakt, że interwencję, czyli wypaczenie zasady wolnorynkowej w krajach rozwijających się realizowano by chronić nierentowne firmy w sektorach priorytetowych (nierentowne, bo poprzednia strategia nie wykorzystywała przewagi komparatywnej). Rządom tych krajów zalecano natychmiastowe zaprzestanie interwencji, co spowodowało upadek starych sektorów priorytetowych i deindustrializację. Konsensus waszyngtoński sprzeciwiał się także przyjęciu przez rząd wytycznych polityki sektorowej, polegających na zapewnieniu zewnętrznych zachęt w postaci rekompensat i przezwyciężeniu niepowodzeń w zakresie koordynacji poprzez ulepszenie niezbędnej twardej i miękkiej infrastruktury w celu ułatwienia wprowadzania firmy do sektora zgodnego z przewagą komparatywną kraju.

W wypadku gospodarek przechodzących transformację od systemu centralnie sterowanego do wolnorynkowego, które w okresie transformacji osiągnęły stabilność i dynamiczny wzrost - takich jak Chiny, Wietnam i Kambodża w latach 80. oraz Mauritius w latach 70., ich rządy przyjęły pragmatyczne podejście dwutorowe. $\mathrm{Z}$ jednej strony, w okresie transformacji zapewniały ciagge wsparcie dla 
nierentownych przedsiębiorstw w starych sektorach priorytetowych, a interwencji zaprzestawały dopiero wtedy, gdy przedsiębiorstwa w tych sektorach zyskały rentowność lub gdy dane sektory zmalały do bardzo nieznacznych rozmiarów. $\mathrm{Z}$ drugiej zaś - o ile przed transformacją prywatne firmy napotykały ze strony rządu same przeszkody, o tyle teraz ułatwiano im wchodzenie do sektorów zgodnych z przewagą komparatywną kraju. Ułatwienia takie przybierały postać tworzenia specjalnych stref ekonomicznych/parków przemysłowych w celu pokonania ograniczeń infrastruktury ${ }^{4}$, świadczenia kompleksowych usług na rzecz poprawy środowiska biznesowego oraz angażowania się w aktywną promocję rozwijanych projektów, aby przyciaggnąc inwestycje zagranicznych firm do tych krajów w ramach ich globalnych łańcuchów wartości. W ten sposób zaś można uzyskać dostęp do rynku światowego (Lin, 2013).

Strategia ta przyczyniła się do osiągnięcia stabilności i dynamicznego rozwoju, a ponadto sprzyja ona mobilizacji kapitału krajowego i bezpośrednich inwestycji zagranicznych (BIZ). Jak na ironię, podejście dwutorowe postrzegane było jako najgorsze podejście do transformacji z punktu widzenia neoliberalizmu (Murphy, Shleifer i Vishny, 1992).

\subsection{Bariery rozwojowe a polityka przemysłowa}

Nowa Ekonomia Strukturalna stoi na stanowisku, że państwo odgrywa zasadniczą rolę w ułatwianiu szybkich innowacji technologicznych, modernizacji przemysłowej i dywersyfikacji ze względu na potrzebę zajęcia się problemami zewnętrznymi i rozwiązania problemów koordynacyjnych w celu poprawy infrastruktury i instytucji. Polityka przemysłowa jest dla państwa użytecznym instrumentem, który służy ułatwianiu transformacji strukturalnej. Wynika to z faktu, że koordynacja, niezbędna dla poprawy infrastruktury i instytucji, może się różnić w poszczególnych branżach przemysłu i miejscach, a zasoby i możliwości rządu są ograniczone, więc rząd musi je wykorzystywać strategicznie5.

Warunkiem sukcesu polityki przemysłowej jest jednak jej nakierowanie na sektory odpowiadające uśpionej przewadze komparatywnej danej gospodarki. Uśpiona przewaga komparatywna odnosi się do przemysłu, który ma konkurencyjne, niskie koszty produkcji na arenie międzynarodowej - czyli zgodne

4 Specjalne strefy ekonomiczne w wielu krajach nie działają $\mathrm{z}$ wielu powodów, takich jak nieprawidłowości w infrastrukturze i/lub brak skutecznych przepisów i wdrażania rozporządzeń, ulokowanie stref w źle dobranych miejscach, powody polityczne lub fakt, że rozwijane w nich docelowe branże przemysłu rozmijały się z tymi, w których kraj miał przewagę komparatywną.

5 Szersze omówienie kwestii roli państwa i polityki przemysłowej - zob. Aghion i Rouglet, 2014; Aghion i in., 2015. 
z określaną przez współczynnik zasobów przewagą komparatywną w kraju - ale w którym koszty transakcji są, ze względu na niewystarczającą twardą i miękką infrastrukturę, zbyt wysokie, aby zyskać konkurencyjność na rynkach krajowych i międzynarodowych.

Firmy działające w branży posiadającej uśpioną przewagę komparatywną będą opłacalne, a całe sektory konkurencyjne, gdy rząd pomoże przedsiębiorstwom pokonać problemy koordynacyjne oraz zewnętrzne z udoskonaleniem twardej i miękkiej infrastruktury w celu obniżenia kosztów i ryzyka w transakcji. W jaki sposób rząd ma wybrać sektory, które są zgodne z uśpioną przewagą komparatywną gospodarki? W zależności od odległości docelowej branży do globalnej granicy technologicznej, Nowa Ekonomia Strukturalna dzieli gałęzie przemysłu w kraju rozwijającym się - szczególnie w kraju wysokiej i średniej zamożności, takim jak Chiny - na pięć kategorii i zaleca rządowi wsparcie zgodnie $\mathrm{z}$ ich potrzebami rozwojowymi (Lin, 2017):

1) branże, w których kraj nadal ma do pokonania dystans do globalnej granicy technologicznej - rząd powinien określić główne niedomagania w zakresie infrastruktury, finansowania, kapitału ludzkiego itd. i pomóc w ich usunięciu;

2) branże, w których kraj znajduje się już na globalnej granicy - rząd powinien wspierać firmy w zakresie prac badawczo-rozwojowych w celu utrzymania pozycji lidera technologicznego na całym świecie;

3) branże, które już utraciły przewagę komparatywną, takie jak pracochłonne gałęzie przemysłu w Chinach - rząd powinien pomóc firmom przejść na branding, projektowanie produktów i zarządzanie marketingowe, czyli dziedziny o wysokiej rentowności lub przenieść produkcję do krajów o niskich kosztach pracy;

4) sektory o krótkich cyklach innowacji, które opierają się bardziej na kapitale ludzkim niż na kapitale fizycznym, w krajach posiadających duży kapitał ludzki (jak Chiny) oraz duży rynek krajowy - rząd może tworzyć parki inkubacyjne, zachęcać do tworzenia kapitałów wysokiego ryzyka oraz chronić własność intelektualną, aby sprzyjać innowacjom;

5) branże strategicznie ważne dla obronności kraju, w których kraj nie posiada przewagi komparatywnej - rząd powinien dotować je bezpośrednio wydatkami fiskalnymi zamiast wspomagać metodami regulacji cen innych interwencji rynkowych. 


\section{Państwo ułatwiające, przywódcy polityczni i idee}

\subsection{Droga do rozwoju}

Problemami dla kraju rozwijającego się mogą być nie tylko przemysł o niskim poziomie produktywności i słaba infrastruktura, lecz także zacofane, zdegenerowane, roszczeniowo nastawione instytucje, których zachowanie kształtuje negatywne zachęty dla społeczeństwa. Nowa Ekonomia Instytucjonalna stoi na stanowisku, że kraj osiągnie dynamiczny wzrost i zamożność, jeżeli jego instytucje będą tworzyły zachęty do pracy, gromadzenia kapitału ludzkiego i fizycznego, zdobywania lepszych technologii i poprawy alokacji zasobów (North i Thomas, 1973; North, 1981; 1990). Jeśli kraj ma źle funkcjonujące instytucje, które nie zachęcają ludzi do starań o osiągnięcie wzrostu gospodarczego, to będzie on słaby i pogrążony w stagnacji. Przykładowo, Acemoglu i in. (2001) oraz Acemoglu i Robinson (2012) twierdzą, że Wielka Brytania i Stany Zjednoczone są bogate, ponieważ posiadają instytucje integracyjne, które ograniczały siłę elit i kształtowały społeczeństwo o równomiernym rozłożeniu praw politycznych. Z kolei Ameryka Łacińska i Afryka są ubogie ze względu na swoje instytucje przemysłu wydobywczego.

Oprócz twierdzenia, że instytucje mają znaczenie, Nowa Ekonomia Instytucjonalna twierdzi również, że są one endogenne i są określane przez inne czynniki społeczne, gospodarcze i polityczne w gospodarce (North, 1981; North i Thomas, 1973). Co więcej, instytucje, które istniały setki lat temu, zachowują istotny wpływ na instytucje obecne oraz na poziom rozwoju gospodarczego, ponieważ instytucje są również kształtowane przez kulturę i historię, a zatem zmiana instytucjonalna podlega zależności ścieżkowej (path dependency) (Acemoglu i in., 2001; North, 1981).

Zgodnie z powyższą logiką, zacofanie instytucji wyjaśnia dlaczego ubogie kraje nie zdołały się rozwinąć. Państwo jako takie oraz ludzie są bezsilni, instytucji nie można bowiem zmienić egzogennie. Jeżeli przyjmie się sposób rozumowania Nowej Ekonomii Instytucjonalnej, badanie zagadnień rozwoju stanie się zajęciem depresyjnym, ponieważ nie jest ono w stanie zaproponować żadnego rozwiązania problemów rozwojowych.

Szybki przegląd gospodarek Cudu Azji Wschodniej (Bank Światowy, 1993) oraz trzynastu odnoszących sukcesy gospodarek w raporcie Komisji ds. Wzrostu Gospodarczego i Rozwoju (2008) pokazuje następujące cechy wspólne: pomimo że wcześniej tkwiły one w ubóstwie i borykały się z problemem złych instytucji, wszystkie posiadały zaangażowane, wiarygodne i zdolne rządy, które przyjęły system praworządności i inne regulacje sprzyjające osiągnięciu nowoczesnego 
wzrostu gospodarczego, jak również strategie rozbudowy eksportu, wykorzystując przewagę komparatywną wynikającą z ich ówczesnych poziomów rozwoju ${ }^{6}$. Oznacza to, że zerwanie jarzma złych instytucji jest możliwe, jeżeli państwo spełnia odpowiednią funkcję.

Patrząc jednak wstecz na wzrost gospodarczy na świecie, nietrudno dostrzec, że większość krajów ubogich nie miała rządów naprawdę świadomych tego, jak rozwijać środowisko biznesowe i zapewniać mu adekwatne, wydajne usługi publiczne (Besley i Persson, 2009; Bardhan, 2016).

Na każdym etapie rozwoju państwo ma odgrywać proaktywną, ułatwiającą rolę. Ograniczenia w rozwoju gospodarczym, które państwo musi usunąć będą różne dla różnych państw, a nawet dla jednego kraju na różnych etapach rozwoju. We wczesnym stadium rozwoju ograniczeniem dla kraju może być jego słaba infrastruktura, niskie umiejętności, złe otoczenie biznesu i zacofane instytucje, a dodatkowo różne zakłócenia i interwencje, jeśli kraj jest w trakcie transformacji ze strukturalnej strategii rozwoju do gospodarki rynkowej.

$\mathrm{Z}$ kolei dla kraju rozwiniętego wyzwaniem jest zapewne zyskanie czołowej pozycji w naukach podstawowych, niezbędnych do rozwijania nowych technologii/produktów lub kwalifikacji do pracy w nowych branżach. Jeżeli skuteczne instytucje i wydajne środowisko biznesowe nie mogą się rozwijać samoczynnie, a sektor prywatny nie jest w stanie zapewnić infrastruktury, konieczne jest, aby państwo wspomagało te dziedziny w interesie rozwoju gospodarki.

\subsection{Rola przywódców politycznych}

Przywódcy polityczni kierują rządem. Jeśli chcemy przeanalizować jakość rządowych wytycznych polityki i przepisów, musimy zrozumieć, co motywuje przywódców politycznych do określania polityki rządu (Lin, 1989). W każdym systemie osobisty interes przywódcy politycznego polega: 1) na utrzymaniu się przy władzy oraz 2) kiedy utrzymanie władzy nie jest zagrożone - na pozostawieniu po sobie dziedzictwa, włącznie z dobrym zapisaniem się w historii (Lin, 2009). Najlepszym sposobem pozostania u władzy i pozostawienia dobrego dziedzictwa jest zapewnienie dobrobytu społeczeństwu. Daje to gwarancję, że przywódca polityczny będzie wspierany przez ludzi, a historia dobrze go zapamięta. Jeżeli jednak idee przyświecające przywódcy politycznemu i jego polityka nie

6 Należy zauważyć, że wiele innych krajów również wprowadziło rządy prawa i inne regulacje, ale nie udało im się osiągnąć nowoczesnego wzrostu gospodarczego. Kluczowe znaczenie ma tu nie to czy wprowadzono rządy prawa, ale czy towarzyszy temu strategia rozwoju promująca rozwój przemysłowy zgodny z przewagami komparatywnymi danego kraju. Zostanie to omówione później. 
przynoszą dobrobytu narodowi, może on stracić poparcie ludu, a jego rola przywódcza może zostać zakwestionowana. Aby utrzymywać się przy władzy, przywódca polityczny może tworzyć grupy interesów wspierane poprzez patronat i umacniać swoją władzę kosztem dobrobytu społecznego, jednak taka postawa prowadzi do powstania błędnego koła. W związku z tym państwo wywłaszczające i chciwe elity można uznać za prawdopodobne konsekwencje niezdolności przywódcy politycznego do zapewnienia społeczeństwu dobrobytu.

Przywódca polityczny jest oczywiście zobowiązany do przestrzegania pewnych konwencji i ograniczony przez elity lub ludzi, którzy dali mu władzę, niemniej może on wykorzystać swoje kompetencje do załatwiania różnych spraw. Kluczem do sukcesu w kraju rozwijającym się o słabej infrastrukturze i instytucjach jest takie wykorzystanie władzy przez przywódców, aby ich działania przekładały się na szybkie sukcesy i na pobudzenie nowoczesnego wzrostu gospodarczego, także tworzenie enklaw w rodzaju specjalnych stref ekonomicznych. Ich dobra infrastruktura i środowisko biznesowe służą przebudzeniu uśpionej przewagi komparatywnej kraju. Takie szybkie sukcesy rozpoczynają samonapędzający się proces generujący więcej środków na rozwijanie infrastruktury i ulepszanie środowiska biznesowego w innych częściach kraju. Szybkie wygrane wzmacniają również autorytet przywódcy politycznego, co daje mu legitymację do przeprowadzania pożądanych reform instytucjonalnych. Wraz z dynamicznym wzrostem pojawia się nowa klasa przedsiębiorczości, a siła starych grup interesów stopniowo maleje. Dlatego to pragmatyczne podejście może być wykorzystane do przerwania impasu instytucjonalnego w kraju nękanym przez roszczeniowe grupy interesów, złe instytucje lub odziedziczone z przeszłości nadmierne zakłócenia rynku i interwencje (Lin i Monga, 2017).

Park Chung-hee w Korei Południowej, Chang Kaj-szek na Tajwanie, Lee Kuan Yew w Singapurze w latach 60. i Deng Xiaoping w Chinach od 1979 roku odegrali instrumentalną rolę w procesie pobudzenia rozwoju, który przekształcił ich gospodarki, pomimo że przed rozpoczęciem dynamicznej transformacji - podobnie jak w innych krajach rozwijających się - tkwiły one w ubóstwie i zmagały się z problemami słabej infrastruktury i złych, zdegenerowanych instytucji. Literatura empiryczna pokazuje, że zmiana przywódcy kraju może mieć duże znaczenie dla wzrostu gospodarczego. Jones i Olken (2005) uważają, że zmiany przywództwa wykazują współzależność ze zmianami tempa rozwoju kraju.

Nawet przywódca polityczny, który zastaje państwo wywłaszczające i pazerne elity może mieć motywację, by użyć powierzonej sobie władzy do skierowania kraju na drogę integracji i szybkiego rozwoju - o ile tylko jest do tego przygotowany mentalnie i myśli takimi kategoriami. Przywódca taki ma największe szanse osiągnąć cel, jeżeli postępuje pragmatycznie i początkowo chroni zastane 
grupy interesów, aby zapewnić sobie stabilność polityczną i społeczną, jednocześnie uruchamiając nowe nisze - tak, jak było to w wypadku dwutorowej transformacji na Mauritiusie w latach 70. XX wieku oraz w Chinach i Wietnamie w latach 80. Celem strategicznym takich działań jest wygenerowanie samonapędzającego się cyklu wzrostu?

\subsection{Trafne pomysły i właściwe strategie rozwoju}

Dążąc do modernizacji, przywódcy polityczni w krajach rozwijających się przyjęli pewne strategie obejmujące zestaw wytycznych polityki, w tym różnych interwencji i rozporządzeń jako sposób na osiągnięcie swoich celów. Zestaw wytycznych polityki kształtował rozwój i jakość instytucji w ich krajach, co z kolei przekładało się na wyniki gospodarcze (Lin, 2009). Ze względu na złożony charakter modernizacji krajów rozwijających się i niejednakowy stopień rozumienia tych zjawisk u przywódców politycznych, za najbardziej praktyczne rozwiązanie w ramach starań o rozwój kraju uznawali oni podążanie za dominującymi ideami społecznymi. I właśnie dominujące idee społeczne kształtowały porządek instytucjonalny państw rozwijających się.

Problem polegał jednak na tym, że w dziedzinie dążenia do modernizacji dominująca myśl społeczna opierała się na błędnej percepcji głównych przyczyn i niedomagań krajów rozwijających się. Wiele strategii powstało pod wpływem poprzednich generacji ekonomii rozwoju, które wprowadzały przywódców politycznych w błąd i skaziły niejedną politykę ekonomiczną w tych krajach. W konsekwencji tego przywódcom nie tylko nie udało się dotrzymać złożonych obietnic, że ich kraje wejdą na drogę takich samych sukcesów, jakie stały się udziałem krajów rozwiniętych, lecz ich posunięcia prowadziły wręcz do stagnacji, częstych kryzysów, a nawet pociągały za sobą katastrofalne następstwa dla ich gospodarek (Lin, 2009). Tylko nieliczne kraje zdołały w tym okresie wydobyć się spod wpływu dominującej myśli społecznej - przykładem tygrysy Azji Wschodniej w latach 60. i Chiny w latach 80. Przywódcy tych rządów nie ulegali nadmiernym wpływom dominującej wówczas myśli społecznej, a ponadto w dobie transformacji przyjęli podejście pragmatyczne ${ }^{8}$.

Transakcje dokonywane bez tarć, kompletne informacje i jasno określone prawa własności - wszystko to są zjawiska pożądane, ale nieczęste w rzeczywistości - zwłaszcza gospodarek rozwijających się. Rząd może próbować narzucić instytucjom styl przeniesiony z kraju rozwiniętego, aby poprawić współczynnik

7 Obszerniejsze omówienie tego zagadnienia: zob. Lin, 2009, rozdz. 2; Lin i Monga, 2017.

8 Szersze omówienie kwestii poważnego wpływu myśli społecznej na wzrost gospodarczy kraju - zob. Buera i Shin, 2010. 
rynkowy i efektywność rynku produktów, zwiększyć przejrzystość informacji, zmniejszyć tarcia w transakcjach itd., ale takie zmiany instytucjonalne są trudne do osiągnięcia, ponieważ instytucje są oporne i podlegają zależności ścieżkowej. Bez endogenicznej siły dążącej do zmian instytucje funkcjonujące według narzuconego stylu mogą nie działać zgodnie z zamierzeniami (Lin, 1989). Konieczne jest zatem zrozumienie i rozwiązanie problemu rozwojowego od strony struktury wyposażenia kapitałowego gospodarki, w tym jej instytucji, zamiast wychodzenia od efektywnych założeń rynkowych neoklasycznej ekonomii.

Częstym problemem krajów o niskich dochodach są zacofane lub zdegenerowane instytucje. W tym kontekście nie jest najważniejsze czy państwo jest dość silne i skuteczne, by przezwyciężyć bariery instytucjonalne, lecz w jaki sposób przywódca polityczny korzysta z przyznanej mu władzy, by pobudzić rozwój. Różnica między Nową Ekonomią Strukturalną a innymi sposobami myślenia o rozwoju jest następująca: Nowa Ekonomia Strukturalna opowiada się za tym, aby kraj rozwijający się trafnie określił, co potrafi robić dobrze w oparciu o posiadane kompetencje i zasoby i aby stworzył warunki do rozbudowy tych dziedzin, a nie koncentrował się na tym, czego nie posiada lub nie potrafi zrobić dobrze, na tym, co wymagałoby atutów posiadanych przez kraje o wysokim dochodzie lub na zdobyciu takich kompetencji i zasobów, i próbach imitowania w tym zakresie krajów o wysokim dochodzie.

Najważniejsze jest, ażeby państwo w sposób pragmatyczny trzymało się właściwej strategii, pozwalającej optymalnie korzystać z zasobów w gospodarce oraz tworzyć zachęty dla poszczególnych prywatnych przedsiębiorstw do prowadzenia działalności gospodarczej, która zwiększy poziom dochodów kraju. Właściwe podejście realizujące właściwy pomysł jest tutaj ważniejsze od silnego państwa zalecanego przez niektórych ekonomistów. Jeśli strategia rozwoju jest zła, silne państwo może spowodować więcej szkód dla własnego społeczeństwa niż słabe państwo. Pod tym względem rację ma North (1981, s. 20), twierdząc, że silne państwo jest mieczem obosiecznym.

Innymi słowy, warunkiem pobudzenia i podtrzymania procesu rozwoju jest skuteczne państwo ułatwiające, które potrafi zapewnić podstawową infrastrukturę publiczną i pomóc gałęziom przemysłu z uśpioną przewagą komparatywną zyskać konkurencyjność poprzez ulepszanie infrastruktury i instytucji. Nawet przy ograniczonej zdolności i zasobach, zastając słabe instytucje i naciski ze strony grup interesów, przywódca polityczny - o ile ma dobre pomysły - i tak ma możliwość umiejętnie korzystać ze swojej władzy do tworzenia enklaw, takich jak specjalne strefy ekonomiczne i parki przemysłowe, $z$ dobrą infrastrukturą i kompleksową obsługą, aby pobudzać dynamiczny rozwój zgodnie z zasadą optymalności Pareto. 
Dynamiczny rozwój, nawet wychodzący od małych enklaw, będzie dawać nadzieję ludziom, wzmocni siłę polityczną przywódcy i wygeneruje więcej środków na dalsze zmiany w gospodarce - przykładem Mauritius, który dzięki swej transformacji osiaggał w latach 70. najlepsze wyniki w Afryce. Kraj ten odziedziczył zachodnią demokrację wielopartyjną, monokulturę rolniczą uprawy cukru, instytucje zaburzone przez strukturalizacyjną strategię zastępowania importu i nie miał silnego państwa, ale osiągnął znaczący wzrost zarówno poziomu życia, jak i potencjału państwa, rozpoczynając transformację od strefy przetwarzania i eksportu wyrobów włókienniczych i odzieżowych w 1970 roku (Subramanian i Roy, 2003). Wartość PKB na jednego mieszkańca w 2016 roku wyniosła tam 9628 USD. W ten sam sposób Chiny, Wietnam i kilka innych krajów Azji Wschodniej jest w stanie rozwijać się dynamicznie, pomimo że ich instytucje były wtedy bardzo słabe, a pomiary dokonywane przy użyciu wielu wskaźników makroekonomicznych, m.in. Doing Business i Indeksu Percepcji Korupcji, wykazują, że ich słabość trwa do dzisiaj.

I odwrotnie - jeżeli idea rozwoju jest zła, jak na przykład strukturalizm dla rozwoju i neoliberalizm dla transformacji, nawet kraj o silnych zdolnościach państwowych, jak obfitujący w zasoby Związek Radziecki, Argentyna i wiele innych krajów Ameryki Łacińskiej lub kraj o zdrowych instytucjach w punkcie wyjścia, jak Filipiny, Indie i inne postkolonialne kraje rozwijające się, będzie miał niską wydajność rozwoju. Dlatego podstawowym wyznacznikiem sukcesu lub porażki rozwoju w każdym kraju w warunkach wstępnych jest idea9 .

\section{Konkluzje}

Od czasów drugiej wojny światowej główny nurt ekonomii został zdominowany przez ekonomię neoklasyczną, w której jednak brakuje roli państwa. Wiele innych form ekonomii rozwoju przewiduje różne role dla rządu, jednak są one niezadowalające.

Strukturalizm opowiada się za państwem rozwojowym i zazwyczaj rekomenduje ambitną industrializację na przekór przewadze komparatywnej. Celem jest tu zbudowanie zaawansowanych, nowoczesnych branż przemysłu i wykorzystanie ochrony rządu i subsydiów jako instrumentów polityki. Neoliberalizm propaguje minimum państwa i sprzeciwia się wykorzystaniu polityki przemysłowej. Jego receptą jest zbudowanie dobrze funkcjonujących instytucji rynko-

9 Więcej szczegółowych argumentów w tym kontekście - zob. Lin, 2009; Lin i Monga, 2017. 
wych, a tezą - że na dobrze funkcjonującym rynku zmiany strukturalne nastąpią samoczynnie.

Ekonomie neoklasyczne poruszają problem wydajnych rynków. Nowa Ekonomia Instytucjonalna stanowi teorię na temat roli instytucji i pokazuje ich znaczenie. Stwierdza, że w kontekście rozwoju najważniejsze jest państwo i właściwe idee. Wyjaśnia i pokazuje, jak osiągnąć optymalne wyniki rozwoju przy danej strukturze wyposażenia - wraz z proaktywną polityką rządu. Nowa Ekonomia Strukturalna stawia państwo i strategię rozwoju oraz transformacji w centrum nowej generacji ekonomii rozwojowej.

Niniejszy artykuł skupia się na roli państwa z punktu widzenia Nowej Ekonomii Strukturalnej. Opowiada się ona za państwem ułatwiającym, którego rola polega na ułatwianiu zmian strukturalnych za pomocą polityki przemysłowej, która pomoże przezwyciężyć niedoskonałości rynku i wesprze branże przemysłu posiadające uśpioną przewagę komparatywną, by mogły one osiągnąć konkurencyjność na rynku. Doktryna ta stoi na stanowisku, że drogą do osiągnięcia stabilności i dynamicznego rozwoju jest pragmatyczne, stopniowe, dwutorowe podejście do problemu transformacji.

Niniejszy artykuł zawiera wskazówki odnośnie do tego, jak rządy powinny kierować gospodarką i podkreśla, że rząd powinien promować gospodarkę w sposób zgodny z jej przewagą komparatywną. Rozwija również teorię państwa ułatwiającego i twierdzi, że w literaturze konwencjonalnej brakowało ważnej roli państwa: wywoływania zmiany instytucjonalnej i ułatwiania rozwoju gospodarczego.

Kraj słabiej rozwinięty cechuje się niską akumulacją kapitału, niskim poziomem kapitału ludzkiego, słabą infrastrukturą i zacofanymi lub zaburzonymi instytucjami, które stanowią barierę dla rozwoju. Autorzy niniejszego artykułu uważają, że przywódcy polityczni mogą odegrać kluczową rolę w kształtowaniu rozwoju narodów. Jednakże w tym kontekście nie jest najważniejsze czy państwo jest silne, czy słabe. Większe znaczenie ma skuteczne przywództwo polityczne i zachowanie pragmatycznego podejścia, czyli niezbędne warunki pobudzenia rozwoju w krajach rozwijających się.

Jeżeli pomysł jest właściwy, to nawet państwo słabe w początkowej fazie przemian może stworzyć enklawy, takie jak specjalne strefy ekonomiczne, aby pomóc krajowym przemysłom z uśpioną przewagą komparatywną zyskać status narodowej przewagi komparatywnej i uruchomić samonapędzający się cykl rozwoju. Jeśli jednak idea nie jest właściwa - na przykład w Chinach strategia nakierowana na przemysł ciężki sprzed transformacji w 1979 roku lub terapia szokowa podczas transformacji w Rosji w latach 90. - może to doprowadzić do powolnego wzrostu dochodów i niskiego poziomu rozwoju gospodarczego, jak miało to miejsce w obydwu wspomnianych wypadkach. 
Autorzy opowiadają się zatem za aktywną rolą państwa, choć w historii - i dawnej i całkiem najnowszej - przeważają porażki rządu w wielu częściach świata. Lewis (1955, s. 376) zauważa: ,żaden kraj nie dokonał postępu gospodarczego bez pozytywnego bodźca ze strony inteligentnych rządów. (...) Z drugiej strony, istnieje wiele przykładów szkody wyrządzonej życiu gospodarczemu przez rządy”. Niemniej, Stiglitz (2011) ma rację, kiedy twierdzi, że interwencje nigdy nie będą idealne - wybór zachodzi pomiędzy niedoskonałymi rządami a niedoskonałymi rynkami, z których każdy ma pełnić funkcję kontrolną dla drugiej strony; należy więc postrzegać je jako komplementarne i szukać równowagi pomiędzy dwiema stronami tego wyboru. Równowagi, która jest nie tylko kwestią rozdzielenia konkretnych zadań pomiędzy te dwie możliwości, lecz także projektowania takich systemów, w ramach jakich możliwości te będą skutecznie ze sobą współgrały.

Aby zmniejszyć ryzyko niewłaściwych interwencji i zwiększyć prawdopodobieństwo sukcesu, Nowa Ekonomia Strukturalna opowiada się za organiczną relacją rynku i państwa, w której „rynek jest skuteczny tylko wtedy, gdy państwo odgrywa rolę ułatwiającą przezwyciężenie nieodłącznych nieprawidłowości w działaniu rynku, a ostatecznym celem ułatwień ze strony państwa jest zagwarantowanie skuteczności rynku". Nowa Ekonomia Strukturalna stwierdza również, że państwa powinny korzystać ze swoich ograniczonych zasobów i możliwości wdrożeniowych pragmatycznie, według starannie określonych priorytetów, aby przezwyciężać ograniczenia i rozbudowywać te branże gospodarki, w których kraj ma uśpioną przewagę komparatywną (rozumianą jako to, co potrafi robić dobrze) w oparciu o posiadane zasoby (czyli to, co aktualnie ma). Jeżeli przywódca polityczny w kraju rozwijającym się realizuje takie zalecenia, każdy rozwijający się kraj ma zdolność pobudzenia ścieżki dynamicznego rozwoju gospodarczego, nawet jeśli od wieków tkwi w ubóstwie i boryka się ze słabą infrastrukturą, zepsutymi instytucjami i naciskami politycznymi grup interesów.

\section{Bibliografia}

Acemoglu, D., Johnson, S. i Robinson, J. (2001). The Colonial Origins of Comparative Development: an Empirical Investigation. American Economic Review, 91(5), 1369-1401. Acemoglu, D. i Robinson, J.A. (2012). Why Nations Fail: The Origins of Power, Prosperity, and Poverty. New York: Random House, Crown Business.

Agenor, P.R., Canuto, O. i Jelenic M. (2012). Avoiding Middle-income Growth Traps. Economic Premise, 98, World Bank.

Aghion, P., Cai, J., Dewatripont, M., Du, L., Harrison, A. i Legros, P. (2015). Industrial Policy and Competition. American Economic Journal: Macroeconomics, 7(4), 1-32. 
Aghion, P. i Roulet, A. (2014). Growth and the Smart State. Annual Review of Economics, 6(1), 913-926.

Bardhan, P. (2016). State and Development: The Need for a Reappraisal of the Current Literature. Journal of Economic Literature, 54(3), 862-892.

Buera, F.J. i Shin, Y. (2010). Financial Frictions and the Persistence of History: A Quantitative Exploration. Journal of Political Economy, 121(2), 221-272.

Commission on Growth Development. (2008). The Growth Report: Strategies for Sustained Growth and Inclusive Development. Commission on Growth and Development Final Report. Washington, DC: World Bank.

Easterly, W. (2001). The Lost Decades: Explaining Developing Countries' Stagnation in Spite of Policy Reform 1980-1998. Journal of Economic Growth, 6(2), 135-157.

Jones, B. i Olken, B. (2005). Do Leaders Matter? National Leadership and Growth Since World War II. Quarterly Journal of Economics, 120(3), 835-864.

Ju, J., Lin, J.Y. i Wang, Y. (2015). Endowment Structures, Industrial Dynamics, and Economic Growth. Journal of Monetary Economics, 76, 244-263.

Keynes, J.M. (1935/1964). The General Theory of Employment, Interest, and Money (first Harbinger edition). New York, Chicago, Brulingame: Harcourt, Brace and World.

Kuznets, S. (1966). Modern Economic Growth: Rate, Structure, and Spread. New Haven, CT: Yale University Press.

Lewis, A. (1966). Theory of Economic Growth. London: Allen and Unwin.

Lin, J.Y. (1989). An Economic Theory of Institution Change: Induced and Imposed Change. Cato Journal, 9(1), 1-33.

Lin, J.Y. (2009). Economic Development and Transition: Thought, Strategy and Viability. Cambridge, UK: Cambridge University Press.

Lin, J.Y. (2012). New Structural Economics: A Framework for Rethinking Development and Policy. Washington DC: the World Bank.

Lin, J.Y. (2013). Demystifying the Chinese Economy. The Australian Economic Review, 46(30), 259-68.

Lin, J.Y. (2017). Industrial Policies for Avoiding the Middle-income Trap: a New Structural Economics Perspective. Journal of Chinese Economic and Business Studies, 15(1), 5-18.

Lin, J.Y. i Monga, C. (2017). Beating the Odds: Jump-starting Developing Countries. Princeton, NJ: Princeton University Press.

Lin, J.Y. i Rosenblatt, D. (2012). Shifting Pattern of Economic Growth and Rethinking Development. Journal of Economic Policy Reform, 15(3), 171-194.

Lucas, R.E., Jr. (1990). Why Doesn't Capital Flow from Rich to Poor Countries? American Economic Review, 80(2), 92-96.

Mankiw, G., Romer, D. i Weil, D.N. (1992). A Contribution to the Empirics of Economic Growth. The Quarterly Journal of Economics, 107(2), 407-437.

Murphy, K.M., Shleifer, A. i Vishney, R.W. (1992). The Transition to a Market Economy: Pitfalls of Partial Reform. Quarterly Journal of Economics, 107(3), 889-906.

North, D.C. (1981). Structure and Change in Economic History. New York: W.W. Norton \& Co.

North, D.C. i Thomas, R.P. (1976). The Rise of the Western World: A New Economic History. Cambridge: Cambridge University Press.

North, D.C., Wallis, J.J. i Weingast, B.R. (2009). Violence and Social Orders: a Conceptual Framework for Interpreting Recorded Human History. Cambridge: Cambridge University Press. 
North, D.C. i Weingast, B.R. (2000). Introduction: Institutional analysis and economic history. The Journal of Economic History, 60(02), 414-417.

Rodrik, D. (2006). Goodbye Washington Consensus, hello Washington Confusion? A Review of the World Bank's Economic Growth in the 1990s: Learning from a Decade of Reform. Journal of Economic Literature, 44(4), 973-987.

Solow, R. (1956). A Contribution to the Theory of Economic Growth. Quarterly Journal of Economics, LXX, 65-94.

Williamson, J. (1990). What Washington Means by Policy Reform. In: J. Williamson (ed.), Latin American Adjustment: How Much Has Happened? Washington: Institute for International Economics.

World Bank. (1993). The East Asian Miracle: Economic Growth and Public Policy. Oxford, UK: Oxford University Press. 